\title{
Design of high efficiency centrifugal compressors stages
}

\author{
M. Kalinkevych ${ }^{1}$, V. Ihnatenko ${ }^{1}$, O. Bolotnikova ${ }^{1}$, O. Obukhov ${ }^{2}$ \\ ${ }^{1}$ Sumy State University, 2 Rymskogo-Korsakova St., Sumy, 40007, Ukraine \\ ${ }^{2}$ Research Center of Rocket Forces and Artillery, 165 Herasyma Kondratieva, Sumy, 40001, Ukraine
}

\begin{abstract}
The modern trend in compressor industry is an extension of the use of multi-shaft centrifugal compressors. Multi-shaft compressors have a number of advantages over single-shaft. The design of such compressors gives opportunity to use an axial inlet for all stages and select the optimum rotational speed for each pair of impellers, which, along with the cooling of the gas after each stage, makes possible to achieve high levels of efficiency. The design of high-efficiency centrifugal compressor stages can be performed on the basis of highly effective stage elements. Such elements are: impellers with spatial blades, vaned and channel diffusers with given velocity distribution. In this paper, impellers with axial-radial blades are considered. The blade profile is determined by the specified pressure distribution along the blade. Such design improves the structure of the gas flow in the interblade channels of the impeller, which leads to an increase in its efficiency. Characteristics of loss coefficients from attack angles for impellers were obtained experimentally. Vaned and channel diffusers, the characteristics of which are given in this article, are designed with the given velocity distribution along the vane. Compared to the classic type of diffuser, such diffusers have lower losses and a wider range of economical operation. For diffusers as well as for impellers, characteristics of loss coefficients from attack angles were obtained. High efficient impellers and diffusers and obtained gas-dynamic characteristics were used in the design of a multi-shaft compressor unit for the production of liquefied natural gas. The initial pressure of the unit is 3bar. The obtained characteristics of loss coefficients from attack angles for the considered impellers and diffusers make it possible to calculate the gas-dynamic characteristics of high-efficient centrifugal compressors stages. The highefficient centrifugal compressors stages can be designed using high-efficient elements, such as: impeller with spatial blades and vaned diffuser with given velocity distribution.
\end{abstract}

Keywords: Centrifugal compressor; Stage; Impeller; Diffuser.

(C) The Author(s) 2018. This article is an open access publication

This work is licensed under the Creative Commons Attribution 4.0 International License (CC BY) http://creativecommons.org/licenses/by/4.0/

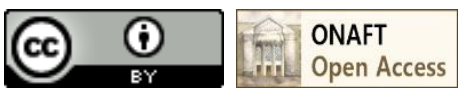

\section{Introduction}

The modern trend in compressor industry is an extension of the use of multi-shaft centrifugal compressors. More than 26 companies in the world produce and supply such compressors with the capacity from 30 to $5000 \mathrm{~m}^{3} / \mathrm{min}$ and discharge pressure up to $5 \mathrm{MPa}$. Multi-shaft compressors have a number of advantages over single-shaft. The design of such compressors gives opportunity to use an axial inlet for all stages and select the optimum rotation velocity for each pair of impellers, which, along with the cooling of the gas after each stage, makes possible to achieve high levels of efficiency. The axial inlet guide vane can be installed in each stage. Minimum dimensions and weight are provided.

The design of high-efficient centrifugal compressor stages can be performed on the basis of highly efficient stage elements. Such elements are: impellers with spatial blades, vaned and channel diffusers with given velocity distribution.

\section{Design and determination of gas dynamic char- acteristics of stage elements}

Impeller. Axial-radial impeller is one of the types of impellers with spatial blades. Axial-radial impellers are usually made without shroud, i.e., they are semi-open im- pellers. A cross-section of a semi-open impeller with axialradial blades is shown in Figure 1.

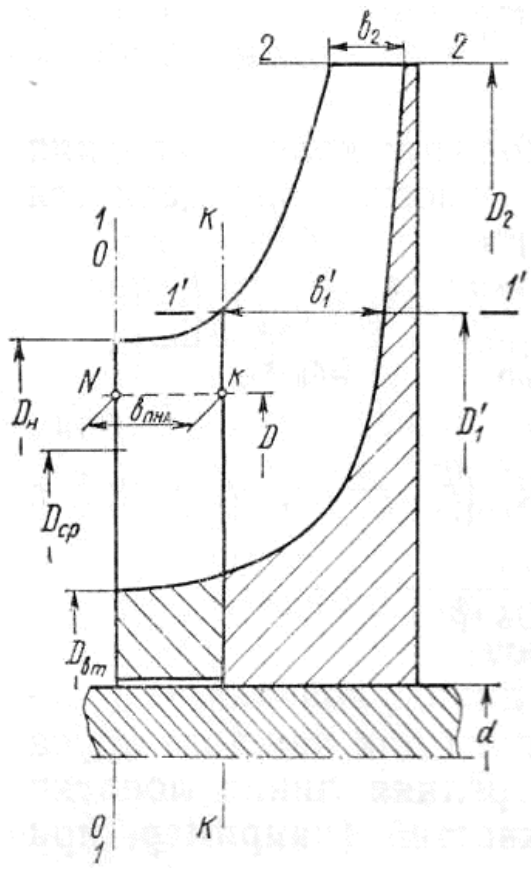

Figure 1 - Cross-section of a semi-open impeller with axial-radial blades 
Axial-radial impellers are usually manufactured from two parts - the axial and radial parts of blades. The input angle $\beta_{b 1}$ of the axial part of blades is performed decreasing from hub to the shroud to ensure unaccented flow in the impeller. The radial part of blades of the impeller is made in the form of radial ribs. Impellers have high strength due to such design of the blades.

The mid-diameter of the inlet $\bar{D}_{1}$ is reduced due to the axial flow inlet on the blades. This reduces flow rates $w_{1}$ and Mach numbers, which decreases the losses.

The axial part of the blades is a diffuser channel with curved axis. This channel has a variable in radius input angle $\beta_{b 1}$ and output angle $\beta_{b 2}=90^{\circ}$.

The shape of the channel for each of its cylindrical cross-section will be different.

The external view of the axial-radial impeller is shown in Figure 2.

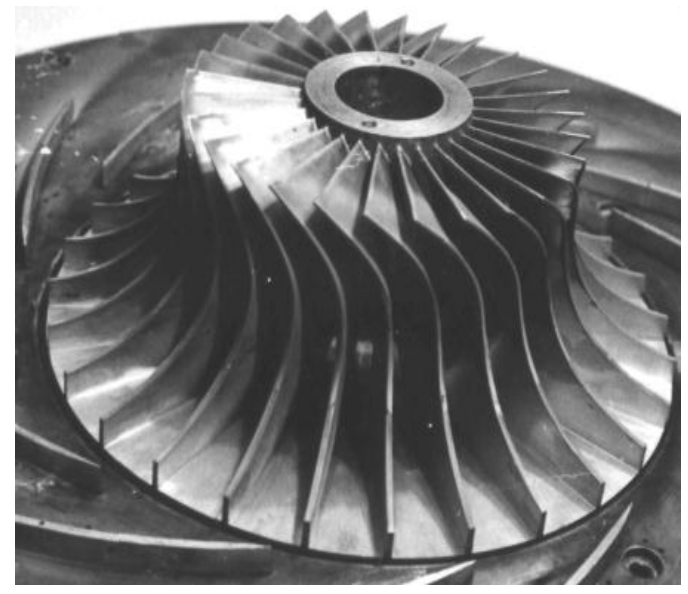

Figure 2 - The semy-open impeller

The experimental data obtained by the author [1] were used to determine the generalized characteristic of impellers with spacial blades (Fig. 3).

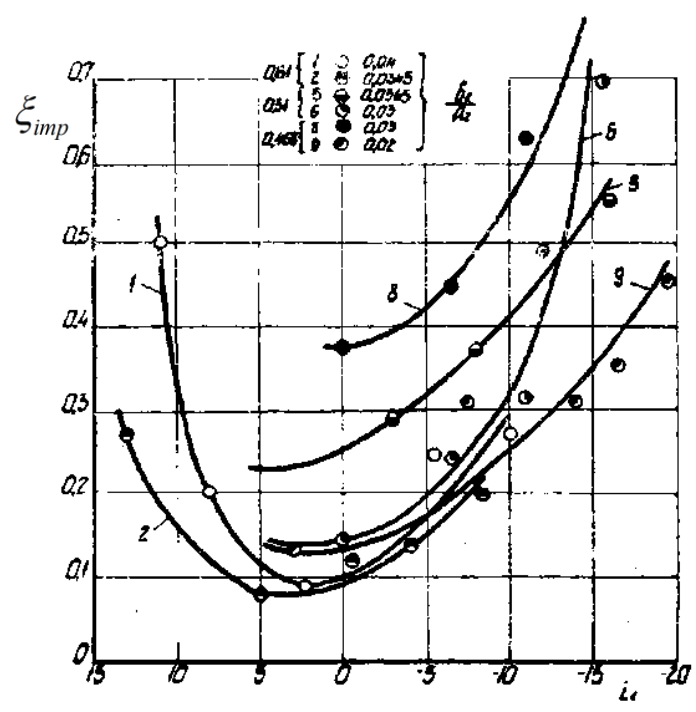

Figure 3 - The experimental data for impeller with special blades
The approximation of the experimental data was carried out using a program «UniAprox2.04» and the analytical form of the generalized characteristics was obtained.

The equation for loss factor of the impeller $\zeta_{\text {imp }}=1,29 \cdot 10^{-3} \cdot i_{1}^{2}+5,96 \cdot 10^{-4} \cdot i_{1}+0,147$. The angle of attack $i_{1}$ in this equation is measured in degrees. Coefficient of determination $R^{2}=99,898 \%$.

Vaned diffuser. The calculation of geometrics of vaned channels is implemented by solving the inverse gas dynamics problem for the given velocity distribution.

The flow of the compressible viscous gas in centrifugal compressors channels may be described by the differential equation obtained from the fundamental conservation law of mechanics. The general set of equation contains continuity equation, momentum equation, angular momentum equation, energy equation, the equation of state, the process equation. It is quite complicated even for the direct problem of gas dynamics to solve this set of equation without any assumptions.

The mathematical model for solving of the inverse problem of gas dynamics was composed for the steady, adiabatic flow without separations.

The experimental data $[2,3]$ were used to determine the generalized characteristic of vaned diffuser (Fig. 4).

The approximation of the experimental data was carried out using a program «UniAprox2.04» and the analytical form of the generalized characteristics was obtained.

The equation for loss coefficient of high-efficiency vaned diffuser

$$
\zeta_{\text {v.dif }}=2,62 \cdot 10^{-3} \cdot i_{3}^{2}+8,36 \cdot 10^{-3} \cdot i_{3}+0,084 \text {. }
$$

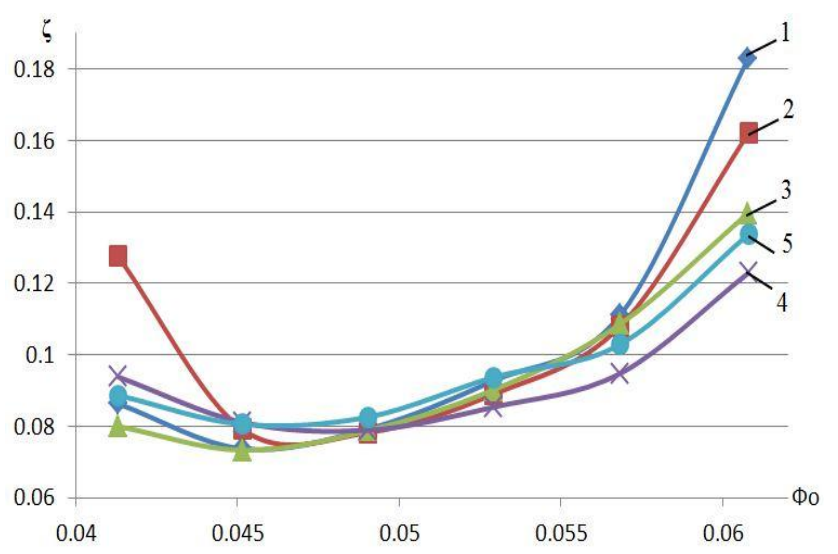

Figure 4 - The experimental data for high-efficiency vaned diffuser

The angle of attack $i_{3}$ in this equation is measured in degrees. Coefficient of determination $R^{2}=99,89 \%$.

Channel diffuser. More effective application of channel diffusers (CD) in comparison with other types of diffusers may be implemented in the next cases: 1) small flow angles at the diffuser inlet; 2) the gas is delivered to the separated cameras from the diffuser channels; 3) diffuser channels turn to the channels of the return element of compressor. 
The design method for channel diffusers of centrifugal compressors, which is based on solving the inverse problem of gas dynamics, is presented in the paper. The presented method of the diffuser design, as opposed to traditional methods, is based on preseparation condition of boundary layer along the pressure surface of the channel diffusers.

Mathematical model for solving the inverse problem of gas dynamics is composed for the steady adiabatic gas flow without separations. The set of equations consists of the angular momentum equation and continuity equation.

Non-dimensional gas dynamic characteristics of designed channel diffuser were obtained by means of CFD calculation.

The experimental data [4] were used to determine the generalized characteristic of channel diffuser (Figure 5).

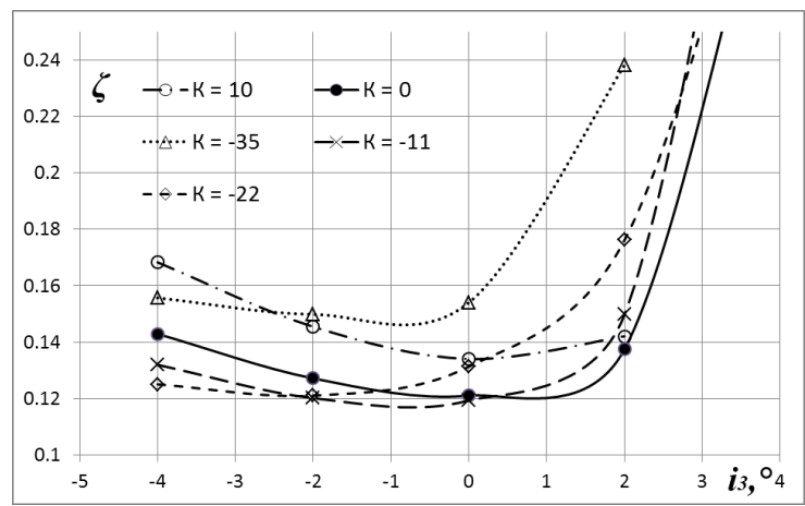

Figure 5 - The experimental data for channel diffuser

The approximation of the experimental data was carried out using a program «UniAprox2.04».

The equation for loss factor of the channel diffuser $\zeta_{\text {c.dif }}=2,08 \cdot 10^{-3} \cdot i_{3}^{2}+5,0 \cdot 10^{-3} \cdot i_{3}+0,121$.

The angle of attack $i_{3}$ in this equation is measured in degrees. Coefficient of determination $R^{2}=99,943 \%$.

\section{The designing of multi-shaft compressor}

The obtained gas-dynamic characteristics are used in the design of a multi-shaft compressor unit. The unit is used for the production of liquefied natural gas with an initial pressure $p_{\text {in }}=3$ bar.

The composition of natural gas: methane $\mathrm{CH}_{4}-0.9863$; ethane $\mathrm{C}_{2} \mathrm{H}_{6}-0.0012$; propane $\mathrm{C}_{3} \mathrm{H}_{8}-0.0023$; n-butane $\mathrm{C}_{4} \mathrm{H}_{10}-0.0001 ; \mathrm{N}_{2}$ nitrogen - 0,0101. Gas constant for this mixture:

$$
R_{\text {mix }}=\frac{8314,9}{\mu_{\text {mix }}}=\frac{8314,9}{16,216}=512,76 \frac{\mathrm{J}}{\mathrm{kg} \cdot \mathrm{K}} .
$$

The initial data for the calculation: capacity $\bar{V}_{s t}=200 \mathrm{st} . \mathrm{m}^{3} / \mathrm{min}$; static pressure at the compressor inlet $p_{\text {in }}=3$ bar; static temperature at the compressor inlet $T_{\text {in }}=288 \mathrm{~K}$; static pressure at the compressor outlet $p_{\text {out }}=22,5$ bar .

The compressor pressure ratio is $\ddot{I}_{c}=22,5 / 3=7,5$. The compressor has with three rotors and six stages. Pressure ratio of the stage is $\Pi=1,4$. The external view of such compressor is shown in Figure 6.

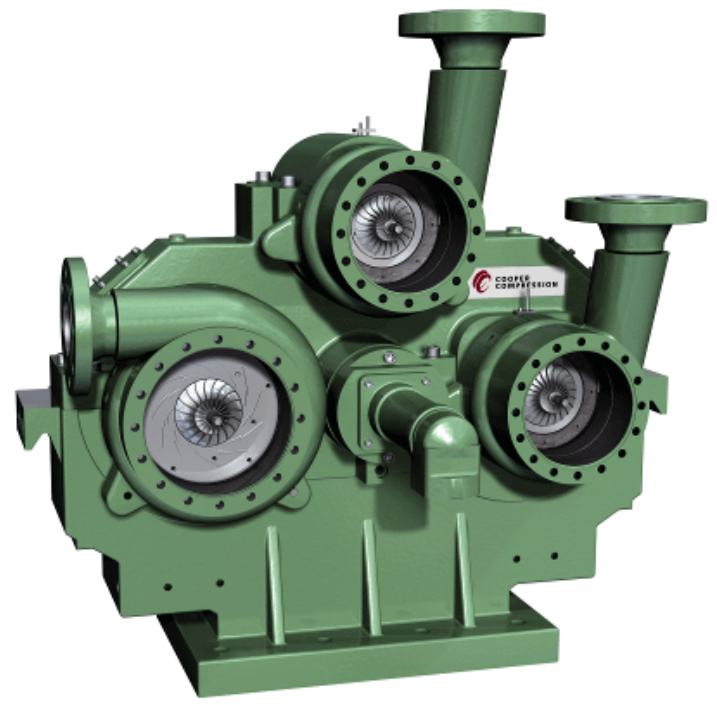

Figure 6 - The external view of the compressor has with three rotors and six stages

Mass flow of the gas

$$
\bar{m}=\bar{V}_{s t} \cdot \rho_{s t}=\frac{200 \cdot 0,674}{60}=2,25 \mathrm{~kg} / \mathrm{s} .
$$

Gas standard density

$$
\rho_{s t}=\frac{p_{s t}}{R \cdot T_{s t}}=\frac{1,013}{512,8 \cdot 293}=0,674 \frac{\mathrm{kg}}{\mathrm{m}^{3}} .
$$

The thermodynamic parameters of the gas at the inlet and outlet of the stages are given in Tables 1 and 2, respectively.

Table 1 - Thermodynamic parameters of gas at the stage inlet

\begin{tabular}{|c|c|c|c|c|c|c|c|}
\hline $\begin{array}{c}\text { No } \\
\text { stage }\end{array}$ & $\begin{array}{c}p_{\text {in }}, \\
\mathbf{b a r}\end{array}$ & $\begin{array}{c}T_{\text {in }}, \\
\mathbf{K}\end{array}$ & $\begin{array}{c}\mathbf{Z} \\
-\end{array}$ & $\begin{array}{c}\rho_{\text {in }}, \\
\mathrm{kg} / \mathrm{m}^{3}\end{array}$ & $\begin{array}{c}i_{\text {in }}, \\
\mathbf{k J} / \mathbf{k g}\end{array}$ & $\begin{array}{c}c_{p}, \\
\mathbf{J} /(\mathbf{k g ~ K})\end{array}$ & $\begin{array}{c}\mathbf{k}, \\
-\end{array}$ \\
\hline I & 3 & 288 & 0,9940 & 2,05 & 599,0 & 2198 & 1,307 \\
\hline II & 4,2 & 300 & 0,9922 & 2,95 & 624,0 & 2232 & 1,303 \\
\hline III & 5,88 & 300 & 0,9896 & 3,95 & 622,6 & 2240 & 1,304 \\
\hline IV & 8,23 & 300 & 0,9844 & 5,96 & 619,7 & 2258 & 1,305 \\
\hline V & 11,5 & 300 & 0,9793 & 7,98 & 616,7 & 2275 & 1,307 \\
\hline VI & 16,1 & 300 & 0,9725 & 10,71 & 612,8 & 2300 & 1,309 \\
\hline
\end{tabular}

In table: $p_{i n}, T_{i n}$ - pressure and temperature of gas at the compressor inlet; $z$ - coefficient of compressibility; $\rho_{i n}-$ gas density at the compressor inlet; $i_{i n}-$ enthalpy at the compressor inlet; $c_{p}$ - heat capacity at constant pressure; $k-$ adiabatic index. 
Table 2 - Thermodynamic parameters of gas at the stage outlet

\begin{tabular}{|c|c|c|c|c|c|c|c|}
\hline $\begin{array}{c}\text { No } \\
\text { stage }\end{array}$ & $\begin{array}{c}p_{\text {out }}, \\
\mathbf{b a r}\end{array}$ & $\begin{array}{c}T_{\text {out }}, \\
\mathbf{K}\end{array}$ & $\begin{array}{c}\mathbf{z} \\
-\end{array}$ & $\begin{array}{c}\rho_{\text {in }}, \\
\mathrm{kg} / \mathrm{m}^{3}\end{array}$ & $\begin{array}{c}i_{\text {in }}, \\
\mathbf{k J} / \mathbf{k g}\end{array}$ & $\begin{array}{c}c_{p}, \\
\mathbf{J} /(\mathbf{k g ~ K})\end{array}$ & $\begin{array}{c}\mathbf{k}, \\
-\end{array}$ \\
\hline I & 4,2 & 316,8 & 0,9936 & 2,801 & 660,1 & 2269 & 1,296 \\
\hline II & 5,88 & 330 & 0,9928 & 3,579 & 690,8 & 2311 & 1,291 \\
\hline III & 8,23 & 330 & 0,9892 & 5,387 & 688,4 & 2325 & 1,293 \\
\hline IV & 11,5 & 330 & 0,9857 & 7,209 & 685,9 & 2338 & 1,295 \\
\hline V & 16,1 & 330 & 0,9811 & 9,658 & 682,6 & 2356 & 1,297 \\
\hline VI & 22,5 & 330 & 0,9731 & 13,99 & 676,8 & 2389 & 1,303 \\
\hline
\end{tabular}

In table: $p_{\text {out }}, T_{\text {out }}-$ pressure and temperature of gas at the compressor outlet; $z$ - coefficient of compressibility; $\rho_{\text {out }}-$ gas density at the compressor outlet; $i_{\text {out }}$ - enthalpy at the compressor outlet; $c_{p}$ - heat capacity at constant pressure; $k-$ adiabatic index.

The parameters given in the tables allow determining the impellers diameters, rotating speed and scaling ratio. Gas-dynamic characteristics of prototype impellers are shown in Figure 7.
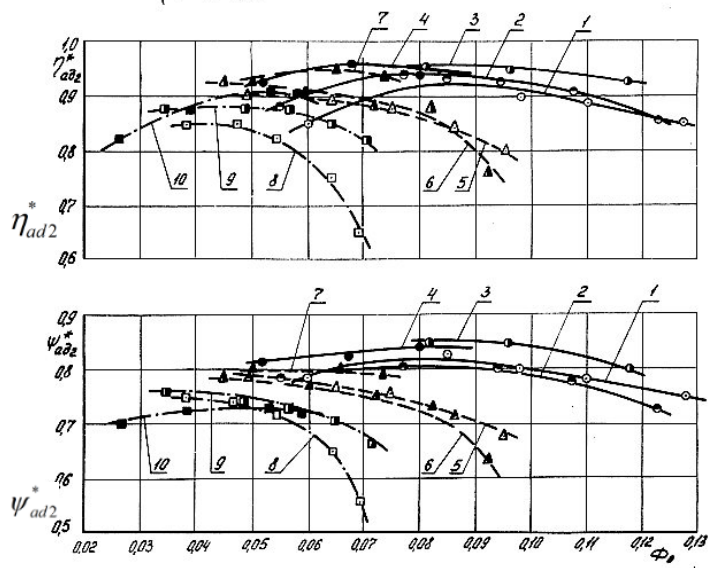

Figure 7 - Gasdynamic характеристики impellers

The head coefficient of the impeller on the operation mode with $\hat{O}_{0}=0,08$

$$
\psi_{i}=\psi_{n} / \eta_{n}=0,82 / 0,93=0,881 .
$$

The impeller angular velocity is determined by the equation $U_{2}=\sqrt{\frac{\Delta i}{\psi_{t}}}, \Delta i$ - enthalpy difference in stage. tion

The diameter of the impeller is determined by the equa-

$$
D_{2}=\sqrt{\frac{4 \cdot \bar{m}}{\pi \cdot U_{2} \cdot \hat{O}_{0} \cdot \rho_{\text {in }}}} .
$$

The rotating speed is determined by the equation

$$
n=\frac{60 \cdot U_{2}}{\pi \cdot D_{2}}
$$

Scaling ratio $k_{m}=\frac{D_{2}}{D_{2 \mathrm{mod}}}$.

For multi-shaft compressors, the diameter of the impeller and the rotation speed are determined for the first compressor stage. For the second stage only the width of the impeller will change.
The width of the impeller is calculated using the equation

$$
\overline{\mathrm{b}}_{2 \mathrm{j}}=\frac{\overline{\mathrm{V}}_{\mathrm{ij}}}{\pi \cdot \varphi_{\mathrm{r} 2} \cdot \varepsilon_{2 \mathrm{j}} \cdot \mathrm{D}_{2}^{2} \cdot \mathrm{u}_{2} \cdot \tau_{2}} .
$$

The results of the calculations are shown in Table 3.

The dimensions of the impeller are determined by the dimensions of the prototype impellers using the scaling ratio.

The main dimensions of vaned diffuser with given velocity distribution are in Table 4 . The airfoil of the vaned diffusers is shown in Figure 8.

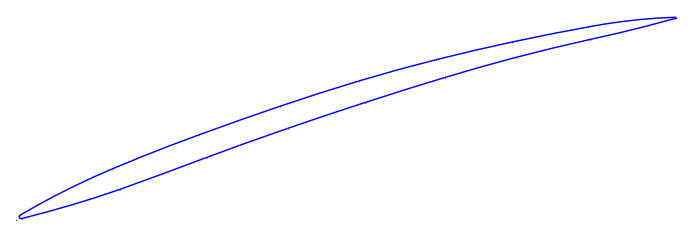

Figure 8 - The airfoil of the vaned diffusers

The characteristics of the compressor and compressor stages are determined by the element-by-element calculation method [5]. Figure 9 shows the gas-dynamic characteristics of the compressor.

The dependences of the pressure ratio $\Pi$ and efficiency $\eta_{p}$ from the mass flow rate of the compressor and the dependence of the pressure ratio $\Pi_{S}$ from mass flow rate of the stage are presented. The compressor has a wide range of economical operation and a high efficiency maximum.

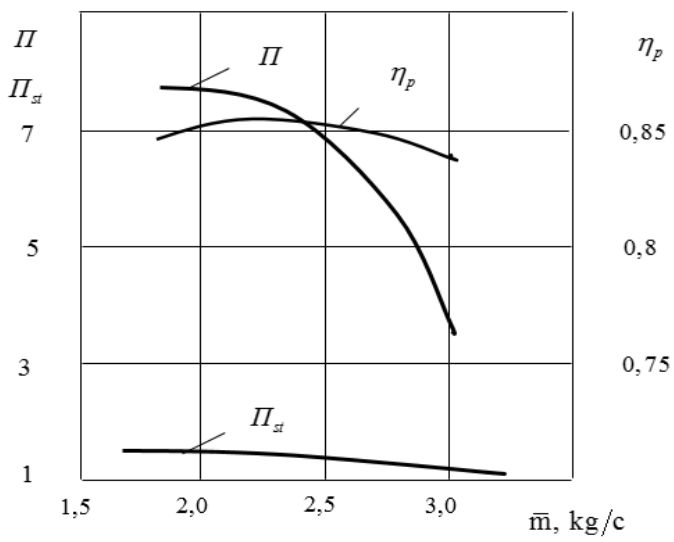

Figure 9- Gas-dynamic characteristics of the compressor 
Table 3 - The main parameters of the impeller

\begin{tabular}{|c|c|c|c|c|c|c|c|}
\hline Parameter & Units & I & II & III & IV & V & VI \\
\hline$\Delta i$ & $\mathrm{~kJ} / \mathrm{kg}$ & 61 & 65,2 & 65,8 & 66,2 & 65,9 & 64 \\
\hline $\bar{V}_{i n}$ & $\mathrm{~m}^{3} / \mathrm{min}$ & 65,9 & 45,7 & 34,2 & 22,7 & 16,9 & 12,6 \\
\hline$U_{2}$ & $\mathrm{~m} / \mathrm{s}$ & 268 & 268 & 273,7 & 273,7 & 271,6 & 271,6 \\
\hline$D_{2}$ & $\mathrm{~m}$ & 0,255 & 0,255 & 0,182 & 0,182 & 0,129 & 0,129 \\
\hline $\mathrm{n}$ & $\mathrm{rpm}$ & 20080 & 20080 & 28735 & 28735 & 40230 & 40230 \\
\hline$b_{2} / D_{2}$ & - & 0,05 & 0,035 & 0,05 & 0,035 & 0,05 & 0,035 \\
\hline $\mathrm{k}_{\mathrm{m}}$ & - & 0,67 & 0,67 & 0,48 & 0,48 & 0,34 & 0,34 \\
\hline
\end{tabular}

Table 4 - The main parameters of the vaned diffuser

\begin{tabular}{|c|c|c|c|c|c|c|c|}
\hline Parameters & Units & I & II & III & IV & V & VI \\
\hline$b_{3}$ & $\mathrm{~m}$ & 0,0153 & 0,0108 & 0,0108 & 0,0076 & 0,0076 & 0,0054 \\
\hline$c_{3}$ & $\mathrm{~m} / \mathrm{s}$ & 216 & 216 & 212 & 212 & 220 & 219 \\
\hline$p_{3}$ & $\mathrm{bar}$ & 3,75 & 5,6 & 7,6 & 11,3 & 15,3 & 20,1 \\
\hline$T_{3}$ & $\mathrm{~K}$ & 306 & 318 & 320 & 320 & 320 & 319 \\
\hline$\rho_{3}$ & $\mathrm{~kg} / \mathrm{m}^{3}$ & 2,41 & 3,44 & 4,7 & 7,0 & 9,5 & 12,5 \\
\hline$\alpha_{b 3}$ & $\mathrm{grad}$ & 16 & 16 & 16 & 16 & 16 & 16 \\
\hline$\alpha_{b 4}$ & $\mathrm{grad}$ & 22 & 22 & 22 & 22 & 22 & 22 \\
\hline$D_{4}$ & $\mathrm{~m}$ & 0,46 & 0,46 & 0,33 & 0,33 & 0,23 & 0,23 \\
\hline$c_{4}$ & $\mathrm{~m} / \mathrm{s}$ & 128,7 & 127,5 & 126 & 127 & 130 & 131 \\
\hline$p_{4}$ & $\mathrm{bar}$ & 4,14 & 6,1 & 8.3 & 12,4 & 16,8 & 22,0 \\
\hline$T_{4}$ & $\mathrm{~K}$ & 314,6 & 326,6 & 328 & 328 & 329 & 327 \\
\hline$\rho_{4}$ & $\mathrm{~kg} / \mathrm{m}^{3}$ & 2,58 & 3,7 & 4,97 & 7,5 & 10,1 & 13,4 \\
\hline$z_{3}$ & - & 7 & 7 & 7 & 7 & & 7 \\
\hline
\end{tabular}

\section{Conclusions}

The high-efficient centrifugal compressors stages can be designed using high-efficient elements, such as: impeller with spatial blades and vaned diffuser with given velocity distribution.

The obtained characteristics of loss coefficients from attack angles for the considered impellers and diffusers make it possible to calculate the gas-dynamic characteristics of high-efficient centrifugal compressors stages.

\section{References}

1. Kalinkevych M. (1976). Investigation of high-pressure stages with axial-radial impellers for stationary general-use compressors (in Russian). Dissertation for the degree of Ph.D. Leningrad Polytechnic Institute. Leningrad.

2. Kalinkevych M, Obukhov O. (2011). The design of vaned diffusers of centrifugal compressors based on the given velocity distribution. 7th International Conference on Compressors and their Systems. City University London, UK. pp. 61-69.
3. Kalinkevych M., Obukhov O., et al. (2015). Analysis of the gas-dynamic performance of a vaned diffuser with given velocity distribution along the vane's surfaces. IOP Conference Series: Materials Science and Engineering, Volume 90, 9th International Conference on Compressors and their Systems: London, UK.

DOI: 10.1088/1757-899X/90/1/012045.

4. Kalinkevych M., Skoryk A. (2013). Design Method for Channel Diffusers of Centrifugal Compressors. International Journal of Rotating Machinery, Vol. 1, 7 pages, Article ID 589357. DOI: 10.1155/2013/589357.

5. Kalinkevych M., Bobrov A., Mykhailova J. (2004). Gazdynamic characteristics of the centrifugal compressor software element-by-element calculation (in Russian). Kompressorna texnika i pnevmatika v XXI veke. XIII Megdunarodna nauchno-texnicheska konferencia po kompressorostroeniu. - Sumy: Izd-vo SumGU. Pp. 190-197.

Received 08 July 2018 Approved 04 September 2018 Available in Internet 30 September 2018 


\title{
Проектування високоефективних ступенів відцентрових компресорів
}

Калінкевич Н. В. ${ }^{1}$, Ігнатенко В. М. ${ }^{1}$, Болотникова Е., Обухов О. А. ${ }^{2}$

${ }^{1}$ Сумський державний університет, вул. Римського-Корсакова, 2, Суми, 40007, Україна

${ }^{2}$ Науково-дослідний центр ракетнах військ и артилерії, вул. Герасима Кондрат'єва, 165, м. Суми, 40001

\begin{abstract}
Сучасною тенденцією в компресоробудуванні є розширення застосування многовальних інтегрованих відиентрових компресорів. Многовальні компресори мають ряд незаперечних переваг у порівнянні з одновальними. Конструкиія таких компресорів забезпечує можливість застосування осьового входу для всіх ступенів, можливість вибору оптимальної частоти обертання для кожної пари робочих колес, щуо, поряд з охолодженням газу після кожного ступеня, дозволяє досягти високих ККД. Проектування високоефективних ступенів відиентрових компресорів може бути виконано на основі високоефективних елементів ступеню. Такими елементами $\epsilon:$ робоче колесо з просторовими лопатками, лопаткові або канальні дифузори, спроектовані по заданому розподілу швидкостей уздовж поверхонь лопаток. В даній роботі розглянуто робочі колеса з осерадіальними лопатками, профіль яких визначено за заданим розподілом тисків уздовж лопатки. Таке проектування покращує структуру потоку газу в міжлопаткових каналах колеса, щзо призводить до зростання його ефективності. Експериментальні дані для колес з осерадіальними лопатками були використані для отримання узагальненої залежності коефіцієнтів втрат від кута атаки. Лопаткові і канальні дифузори, характеристики яких наведені в иій статті, спроектовані по заданому розподілу швидкостей уздовж лопатки. Такі дифузори, у порівнянні з тими, щзо звичайно застосовуються, у яких середня лінія лопаток виконана по дузі кола, мають менші втрати $і$ більш широку зону економічної роботи. Як $і$ для робочих колес, для дифузорів були отримані узагальнені залежності коефіцієнтів втрат від кутів атаки. Високоефективні робочі колеса і дифузори використано при проектуванні многовального компресора з початковим тиском. Результати проектування демонструють, щзо отримані залежності коефіцієнтів втрат від кутів атаки для робочого колеса з осерадіальними лопатками та лопаточного дифузора з заданим розподілом швидкостей дозволяють розрахувати газодинамічні характеристики високоефективних ступенів відиентрових компресорів.япроектування показують, щяо отримані залежності коефіцієнтів втрат від кутів атаки для робочого колеса з осерадіальнимі лопатками $i$ лопаточного дифузора з заданим розподілом швидкостей дозволяють розрахувати газодинамічні характеристики високоефективних ступенів відцентрових компресорів.
\end{abstract}

Ключеві слова: відиентровий компрессор; Ступінь; Робоче колесо; Дифузор

\section{Література}

1. Калинкевич Н. В. Исследование высоконапор-ных ступеней с осерадиальными колесами для стационарных компрессоров общего назначения / Диссертация на соискание степени кандидата технических наук. Ленинградский политехнический институт. Ленингпад. 1976. $-252 \mathrm{c}$.

2. Kalinkevych M, Obukhov O., et al. The design of vaned diffusers of centrifugal compressors based on the given velocity distribution. / 7th International Conference on Compressors and their Systems. City University London, UK. - 2011. pp. 61 - 69. ISBN 978-0-85709-535-0 (ebook).

3. Kalinkevych M., Obukhov O., et al. Analysis of the gasdynamic performance of a vane diffuser with given velocity distribution along the vane's surfaces. IOP Conference Se- ries: Materials Science and Engineering, Volume 90, 9th International Conference on Compressors and their Systems: London, UK. -2015. DOI: 10.1088/1757899X/90/1/012045.

4. Kalinkevych M., Skoryk A. Design Method for Channel Diffusers of Centrifugal Compressors. International Journal of Rotating Machinery, Vol. 1, 7 pages, Article ID 589357. - 2013. DOI: 10.1155/2013/589357.

5. Калинкевич Н. В., Бобров А. Н., Михайлова Ю. Ю. Программное обеспечение поэлементного расчета газодинамических характеристик центробежного компрессора / Компрессорная техника и пневматика в XXI веке. XIII Международная научно-техническая конференция по компрессоростроению. - Сумы: Изд-во СумГУ. 2004. - C. 190-197.

\footnotetext{
Отримана в редакції 08.07.2018, прийнята до друку 04.09.2018
} 